\title{
$\alpha$-Melanocyte-stimulating hormone directly increases the plasma calcitonin level and involves calcium metabolism in goldfish
}

\author{
Takahiro Ikari · Yuki Kobayashi • Yoichiro Kitani · Toshio Sekiguchi • \\ Masato Endo • Akira Kambegawa · Kiyoshi Asahina • Atsuhiko Hattori • \\ Yoshiaki Tabuchi $\cdot$ Thumronk Amornsakun $\cdot$ Kanta Mizusawa $\cdot$ \\ Akiyoshi Takahashi $\cdot$ Nobuo Suzuki i
}

Received: 27 June 2018/Accepted: 18 September 2018/Published online: 29 September 2018

(C) The Author(s) 2018

\begin{abstract}
The effects of $\alpha$-melanocyte-stimulating hormone ( $\alpha$-MSH) on calcium metabolism were examined with goldfish. The scales on the left side of goldfish bodies were removed to allow the regeneration of scales under anesthesia. Thereafter, the influences of $\alpha$-MSH injection (low dose: $0.1 \mu \mathrm{g} / \mathrm{g}$ body weight; high dose: $1 \mu \mathrm{g} / \mathrm{g}$ body weight) on plasma calcitonin (calcium-regulating hormone) and the calcium content of the scales were investigated. Ten days after removing the scales, we measured the plasma calcitonin and calcium content of both regenerating scales on the left side and ontogenic scales on the right side. At both doses of $\alpha$-MSH injection, plasma calcitonin concentrations in the $\alpha-\mathrm{MSH}$-treated group were significantly higher than those in the control group. The mRNA expressions of $\alpha$-MSH-receptors were detected in the ultimobranchial glands (secretory organ of calcitonin), indicating that $\alpha-\mathrm{MSH}$ directly functions in ultimobranchial glands and promotes calcitonin secretion. Furthermore, we found that the calcium content of regenerating scales in $\alpha$-MSHtreated goldfish was higher than that in control goldfish, while the calcium content of ontogenic scales on the right side was significantly decreased by $\alpha$-MSH injection. There was a significant co-relationship between plasma calcitonin and the calcium content of regenerating scales. The mRNA expression of calcitonin receptors in regenerating scales was remarkably higher than that in ontogenic scales. These results imply that calcitonin functions to promote scale regeneration resulting from the inhibition of bone resorption because
\end{abstract}

T. Ikari $\cdot$ Y. Kitani $\cdot$ T. Sekiguchi $\cdot$ N. Suzuki $(\bowtie)$

Noto Marine Laboratory, Division of Marine Environmental Studies, Institute of Nature and Environmental Technology,

Kanazawa University, Noto-Cho, Ishikawa 927-0553, Japan

e-mail: nobuos@staff.kanazawa-u.ac.jp

Y. Kobayashi

Graduate School of Integrated Arts and Sciences, Hiroshima University, Higashi-Hiroshima 739-8521, Hiroshima, Japan

M. Endo

Department of Marine Biosciences, Division of Marine Science, Tokyo University of Marine Science and Technology, Minato-Ku, Tokyo 108-8477, Japan

A. Kambegawa

The Kambegawa Laboratory, Komae, Tokyo 201-0013, Japan

K. Asahina

Department of Marine Science and Resources, College of Bioresource Sciences, Nihon University,

Fujisawa 252-0813, Kanagawa, Japan

A. Hattori

Department of Biology, College of Liberal Arts and Sciences, Tokyo Medical and Dental University, Ichikawa,

Chiba 272-0827, Japan 
calcitonin suppresses osteoclastic activity. Thus, we are the first to demonstrate the interaction between $\alpha$ MSH and calcitonin in teleosts.

Keywords $\alpha$-Melanocyte-stimulating hormone $\cdot$ Calcitonin $\cdot$ Calcium $\cdot$ Fish scales $\cdot$ Ultimobranchial glands . Scale regeneration

\title{
Introduction
}

Alpha-melanocyte-stimulating hormone ( $\alpha-\mathrm{MSH})$, which is composed of 13 amino acids, is a proteolytic cleavage product generated from adrenocorticotropic hormone (Takahashi and Kawauchi 2006; Brzoska et al. 2008; Takahashi and Mizusawa 2013). The amino acid sequence of $\alpha$-MSH is well conserved among vertebrates and functions in several tissues via melanocortin receptors (Brzoska et al. 2008; Takahashi and Mizusawa 2013; Dores et al. 2016). Recently, a new function of $\alpha$-MSH has been determined. In mammals, namely, it has been reported that $\alpha$-MSH directly functions in bone metabolism (Farooqi et al. 2000) and promotes bone resorption (Cornish et al. 2003). Furthermore, Cornish et al. (2003) reported that trabecular bone volume was reduced by $22 \%$ with the administration of $\alpha$-MSH to mice ( 20 injections of $4.5 \mu \mathrm{g} / \mathrm{day}$ ). Therefore, $\alpha$-MSH is one hormone that regulates bone metabolism in mammals.

In teleosts as well as mammals, we previously demonstrated that $\alpha$-MSH functions in goldfish scales and induces hypercalcemia resulting from the promotion of bone resorption (Ishizu et al. 2018). In vertebrates, including teleosts, the plasma calcium concentration is maintained at a constant level by hormonal regulation. This implies that hypocalcemic hormones such as calcitonin respond to hypercalcemia in goldfish (Carassius auratus). In eels, Anguilla japonica (freshwater teleosts), plasma calcitonin levels actually increased with the rise of plasma calcium caused by the dietary uptake of calcium (Suzuki et al. 1999). In stonefish, Inimicus japonicus (marine teleosts) also, both plasma calcium and calcitonin levels increased after the administration of a high-calcium solution into the stomach (Kaida and Sasayama 2003). Thus, we focused on the relationship between $\alpha$-MSH and calcitonin.

On the other hand, teleost scales are functional internal calcium reservoirs involved in calcium metabolism, particularly in freshwater teleosts such as goldfish (Mugiya and Watabe 1977; Suzuki et al. 2008, 2016). Additionally, it is known that teleost scales regenerate after being removed (Bereiter-Hahn and Zylberberg 1993; Suzuki et al. 2009; Yoshikubo et al. 2005). During scale regeneration, both osteoblastic and osteoclastic activities in regenerating scales were higher than those in ontogenic scales (Yoshikubo et al. 2005). As $\alpha$-MSH induced hypercalcemia (Ishizu et al. 2018), we strongly believe that $\alpha$-MSH involves calcium metabolism related to scale regeneration.

Thus, in the present study, the influence of $\alpha$-MSH injection on calcium regulation during scale regeneration was examined in goldfish. In brief, after $\alpha$-MSH administration, plasma calcitonin (calcium-regulating hormone) and the calcium content of both regenerating and ontogenic scales were investigated in the present study. Furthermore, we analyzed the expression of $\alpha$-MSH and calcitonin receptors. Our investigation is the first to demonstrate the interaction between $\alpha-\mathrm{MSH}$ and calcitonin in teleosts.

\author{
Y. Tabuchi \\ Division of Molecular Genetics Research, Life Science Research Center, University of Toyama, Toyama 930-0194, Japan \\ T. Amornsakun \\ Fisheries Technology Program, Faculty of Science and Technology, Prince of Songkla University, Pattani 94000, Pattani, \\ Thailand \\ K. Mizusawa - A. Takahashi \\ School of Marine Biosciences, Kitasato University, Sagamihara, Kanagawa 252-0373, Japan
}




\section{Materials and methods}

Animals

One pair of female and male goldfish (Carassius auratus) was artificially fertilized at the Graduate School of Marine Science and Technology, Tokyo University of Marine Science and Technology (Suzuki et al. 2009). After the hatched goldfish grew to a body length of about $12 \mathrm{~cm}$, these fish $(n=40)$ were transferred to Noto Marine Laboratory at Kanazawa University, and used for an in vivo experiment. To avoid the effects of sex hormones, non-breeding goldfish were used in the present study. All experimental procedures were conducted in accordance with the Guide for the Care and Use of Laboratory Animals prepared by Kanazawa University.

Effects of $\alpha$-MSH on plasma calcitonin and the calcium content of both regenerating and ontogenic scales in goldfish

In both control and experimental groups, normally developed scales on the left sides of goldfish were removed to allow the regeneration of scales under anesthesia with $0.03 \%$ ethyl 3-aminobenzoate and methanesulfonic acid salt (Sigma-Aldrich, Inc., St. Louis, MO, USA) neutralized with $0.03 \%$ sodium bicarbonate. Thereafter, the influence of $\alpha$-MSH on the calcium metabolism regarding scale regeneration was studied. Namely, $\alpha$-MSH was administered at a low dose $(0.1 \mu \mathrm{g} / \mathrm{g}$ body weight $)$ or a high dose $(1 \mu \mathrm{g} / \mathrm{g}$ body weight $)$ to goldfish every other day in the morning. During all experimental periods, goldfish were kept at $26^{\circ} \mathrm{C}$ under a daily photoperiod cycle of 12-h light: 12-h darkness (Suzuki et al. 2009). Saline (0.9\% NaCl) was injected into the goldfish in the control group in the same manner as in the experimental group (each $n=8$ ). During the experimental periods, both experimental and control goldfish were fed every morning. Ten days after scale removal, we collected both the regenerating scales on the left side, and ontogenic scales on the right side. The scale-calcium content [mg/dry weight (mg) of scale] was determined using the Calcium C kit (Wako Pure Chemical Industries, Ltd., Osaka, Japan) with a microplate reader after the dried scale $\left(60{ }^{\circ} \mathrm{C}, 12 \mathrm{~h}\right)$ had been dissolved in nitric acid and then neutralized by $\mathrm{NaOH}$ (Suzuki et al. 2004, 2011). After removing the regenerating scales and ontogenic scales, blood samples were collected from the caudal vessel using a heparinized capillary from anesthetized goldfish. After centrifugation at 15,000 rpm for $3 \mathrm{~min}$, the plasma was immediately frozen and kept at $-80^{\circ} \mathrm{C}$.

Plasma calcitonin levels were measured by enzyme-linked immunosorbent assay (ELISA). The procedures of ELISA have been described in detail by Suzuki (2001). The detection limit was $25 \mathrm{pg} / \mathrm{ml}$ (Suzuki 2001). The specificity of anti-salmon calcitonin serum (No. 626, Cosmo Bio Co., Ltd., Tokyo, Japan) was checked using peptide hormones (N-terminal fragment of 1-34 bovine parathyroid hormone and human calcitonin gene-related peptide). This anti-serum did not cross-react to these peptide hormones.

The mRNA expressions of melanocortin receptors (MCRs) in the ultimobranchial glands of goldfish

We examined the mRNA expression of melanocortin receptors (MCRs) in the ultimobranchial glands, which are the secretory organ of calcitonin. The ultimobranchial glands were dissected from goldfish (three males and three females) under anesthesia with $0.03 \%$ ethyl 3-aminobenzoate and methanesulfonic acid salt (SigmaAldrich) neutralized with $0.03 \%$ sodium bicarbonate. Also, the brains were removed from goldfish (one male and one female) as a positive control (Mizusawa et al. 2018). Total RNAs were prepared from dissected ultimobranchial glands and brains using a total RNA isolation kit (NucleoSpin RNA II, Takara Bio, Inc., Shiga, Japan) and treated with DNase I (RNase-Free DNase Kit, Takara Bio, Inc.) for 15 min at room temperature to remove residual genomic DNA. Complementary DNA synthesis was also performed using a kit (PrimeScript $^{\mathrm{TM}}$ II 1st strand cDNA Synthesis Kit, Takara Bio, Inc.).

The specific primers for the MCRs (melanocortin 1 receptor: MC1R; melanocortin 2 receptor: MC2R; melanocortin 3 receptor: MC3R; melanocortin 4 receptor: MC4R; melanocortin 5 receptor: MC5R) (Table 1) were used (Kobayashi et al. 2011). The sample on which PCR was performed with the addition of reverse transcriptase was compared with a sample on which PCR was performed without reverse transcriptase as a negative control. $\beta$-actin was used as a housekeeping gene (Kobayashi et al. 2011). The primer sequences of $\beta$-actin are described in Table 1 . The conditions for PCR amplification were 40 for MCRs or 35 for $\beta$-actin 
Table 1 Custom oligonucleotide primers used for the expression analysis of MCRs in the ultimobranchial glands of goldfish

\begin{tabular}{|c|c|}
\hline Target & Nucleotide sequence \\
\hline MC1R & FW 5'-GCT TGT CAC GGC AAA GAT GT-3' \\
\hline MC1R & RV 5'-TGG CTT GTC GGC GAC TCT TA-3' \\
\hline $\mathrm{MC} 2 \mathrm{R}$ & FW 5'-ACA CCT GAA CGG TCG TTT CG- $3^{\prime}$ \\
\hline $\mathrm{MC} 2 \mathrm{R}$ & RV 5'-CTC AAG CCA CTT TGT CTC TG-3' \\
\hline MC3R & FW 5'-TGT CTG TTC TTCCCC ATC TC-3' \\
\hline MC3R & RV 5'-GGC GAT TGT TTA GTA CAG CA-3' \\
\hline MC4R & FW 5'-TGC CTC CGA AAC GGT AGT GA-3' \\
\hline MC4R & RV 5'-GCT GAT AAG GCA GAT GAG AA- $3^{\prime}$ \\
\hline MC5R & FW 5'-CTG TCA CTT TGG GCC ATC AG-3' \\
\hline MC5R & RV 5'-TCT GAT GAA ATG GTC CTC CA-3' \\
\hline$\beta$-actin & FW 5'-TGA AGT ACC CCA TCG AGG CA-3' \\
\hline$\beta$-actin & RV 5'-AGG ATC TTC ATG AGG TAG TC-3' \\
\hline
\end{tabular}

$F W$ forward primer, $R V$ reverse primer

cycles of denaturation for $15 \mathrm{~s}$ at $94{ }^{\circ} \mathrm{C}$, annealing for $30 \mathrm{~s}$ at $60{ }^{\circ} \mathrm{C}$, and extension for $40 \mathrm{~s}$ at $72{ }^{\circ} \mathrm{C}$. PCR products were electrophoresed on 3\% agarose gel (Agarose S, Nippon Gene Co., Ltd., Toyama, Japan) and visualized with $0.025 \%$ ethidium bromide. Photographs were taken using a Densitograph (ATTO Corp., Tokyo, Japan).

Comparison of calcitonin receptor mRNA expression in regenerating scales and ontogenic scales of goldfish

To analyze calcitonin receptor mRNA expression, both regenerating and ontogenic scales from goldfish $(n=10)$ were prepared again.

Total RNAs were prepared from goldfish scales using a total RNA isolation kit (NucleoSpin RNA II, Takara Bio, Inc.), as described above. The PCR amplification was analyzed with a real-time PCR apparatus (Mx3000pTM, Stratagene, La Jolla, CA, USA) using SYBR Premix Ex Taq (Takara Bio, Inc.) (Suzuki et al. 2011; Sato et al. 2017). Real-time qPCR was performed using the specific primer set (forward primer: $5^{\prime}$ AAAGCAGAGCCCACCACTGA-3'; reverse primer: 5'-CTGCTGCAGAACGAACCTGT-3') for calcitonin receptors (Ikari et al. 2018). The annealing temperature for calcitonin receptors was $55^{\circ} \mathrm{C}$ (Ikari et al. 2018). The mRNA expression level of calcitonin receptors was normalized to the mRNA expression level of $\beta$-actin (forward primer: 5'-CGAGCGTGGCTACAGCTTCA-3'; reverse primer: 5'-GCCCGTCAGGGAGCTCATAG- $3^{\prime}$ ) as a housekeeping gene (Azuma et al. 2007). The annealing temperature for $\beta$-actin was $60{ }^{\circ} \mathrm{C}$ (Azuma et al. 2007). The results are shown as the mean $\pm \operatorname{SEM}(n=10$ individual goldfish).

Statistical analysis

All results are expressed as the mean \pm SE. The statistical significance between the control and experimental groups was assessed by Student's $t$ test or by one-way ANOVA followed by Dunnett's test. In all cases, the selected significance level was $p<0.05$.

\section{Results}

Effects of $\alpha$-MSH injection on plasma calcitonin in goldfish

The plasma calcitonin levels are indicated in Fig. $1 . \alpha$-MSH was injected at a low dose $(0.1 \mu \mathrm{g} / \mathrm{g}$ body weight $)$ or a high dose $(1 \mu \mathrm{g} / \mathrm{g}$ body weight $)$ into goldfish every other day. At both doses, plasma calcitonin levels in $\alpha-$ MSH-injected goldfish increased significantly as compared with those in control goldfish. 


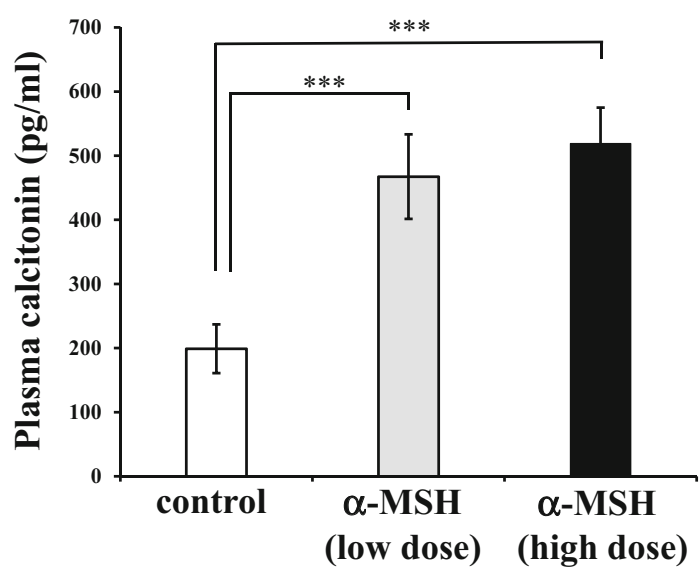

Fig. 1 Effects of $\alpha$-MSH on plasma calcitonin levels in goldfish. $\alpha$-MSH was injected at a low dose $(0.1 \mu \mathrm{g} / \mathrm{g}$ body weight $)$ or a high dose $(1 \mu \mathrm{g} / \mathrm{g}$ body weight) into goldfish every other day. Ten days after injection, we collected plasma samples and analyzed their calcitonin levels. $* * *$ Indicates a statistically significant difference at $p<0.001$ from the values in control scales. $n=8$ samples; one sample from one fish

The mRNA expressions of MCRs in ultimobranchial glands of goldfish

To examine the interaction between $\alpha$-MSH and calcitonin, the mRNA expressions of MCRs were analyzed in the ultimobranchial glands. In males (Fig. 2b) and females (Fig. 2d), MCR1, 2, 3, 4, and 5 were detected in the ultimobranchial glands of goldfish, although variation in the expression level of each individual was observed. $\beta$-actin, as a housekeeping gene, was expressed in each ultimobranchial gland of goldfish (Fig. 2e). On the other hand, the brains of males (Fig. 2a) and females (Fig. 2c), used as a positive control expressed all MCRs. In the sample on which PCR was performed without reverse transcriptase, specific bands were not detected (data not shown).

Effects of $\alpha$-MSH injection on the calcium content of both regenerating and ontogenic scales in goldfish

The calcium content of both regenerating and ontogenic scales in goldfish is shown in Fig. 3. Ten days after the removal of scales, the calcium content of regenerating scales in goldfish treated with high doses of $\alpha$-MSH was significantly higher than that in control goldfish. On the other hand, the calcium content of ontogenic scales on the right side was significantly decreased by high-dose injections of $\alpha$-MSH. There was a significant co-relationship between the plasma calcitonin and calcium content of regenerating scales in both the control and experimental groups (Fig. 4a), although the plasma calcitonin level did not have a co-relationship with the calcium content of the ontogenic scales (Fig. 4b).

Comparison of calcitonin receptor mRNA expression of regenerating and ontogenic scales of goldfish

The mRNA expression of calcitonin receptors was detected in both regenerating and ontogenic scales (Fig. 5). The calcitonin receptor mRNA expression in regenerating scales was remarkably higher than that in ontogenic scales (Fig. 5). There was a significant difference between regenerating scales and ontogenic scales.

\section{Discussion}

Using $\alpha$-MSH-injected goldfish, we are the first to demonstrate the interaction between $\alpha$-MSH and calcitonin in teleosts. In brief, after $\alpha$-MSH administration (low dose: $0.1 \mu \mathrm{g} / \mathrm{g}$ body weight; high dose: $1 \mu \mathrm{g} / \mathrm{g}$ body weight), the plasma calcitonin level increased significantly at both doses (Fig. 1). To examine the direct influence of $\alpha-\mathrm{MSH}$ on calcitonin production, MCR mRNA expression was measured in the ultimobranchial glands of goldfish. As a result, MCR1, 2, 3, 4, and 5 were detected in goldfish ultimobranchial glands (Fig. 2). 
(a) Brain

(b) Ultimobranchial glands

(positive control)

Male No. 1

Male No. 2

Male No. 3

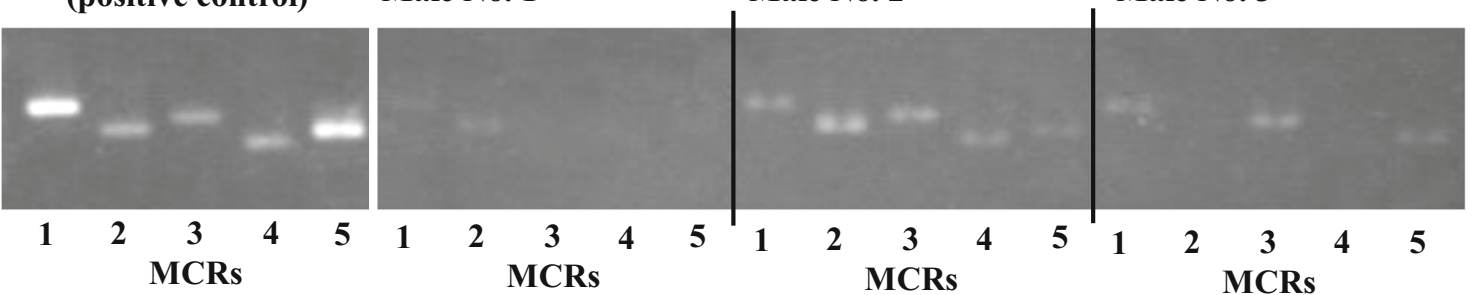

(c) Brain

(positive control)

(d) Ultimobranchial glands

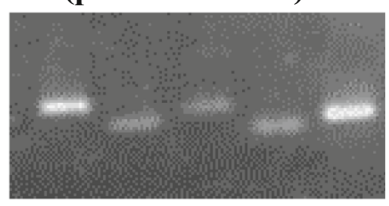

Female No. 1

Female No. 2

Female No. 3

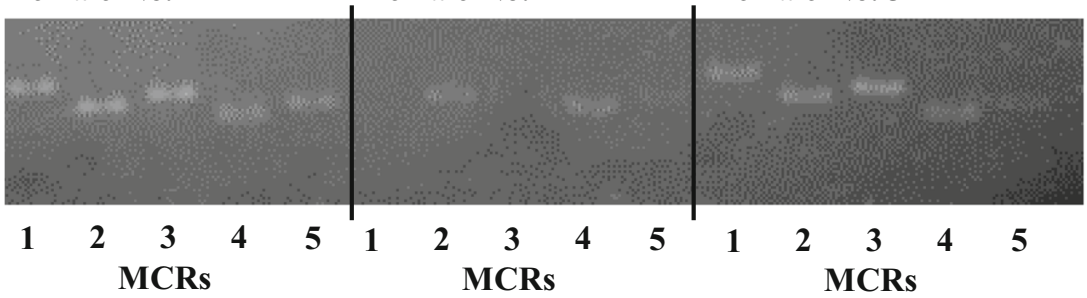

(e) $\beta$-actin (ultimobranchial glands)

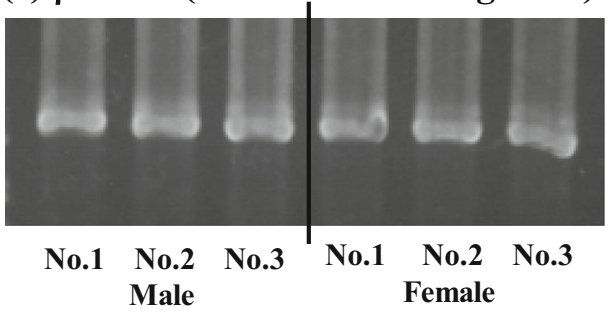

Fig. 2 The expressions of melanocortin receptors' (MCRs: MC1R, MC2R, MC3R, MC4R, and MC5R) mRNA in the brains (a male; c female) and ultimobranchial glands (b male; d female) of goldfish. The mRNA was prepared from the brains or ultimobranchial glands of male and female goldfish. The mRNA expressions of MCRs were analyzed in brains or ultimobranchial glands. $\beta$-actin was used as a housekeeping gene (e) (Kobayashi et al. 2011)

(a) Regenerating scale

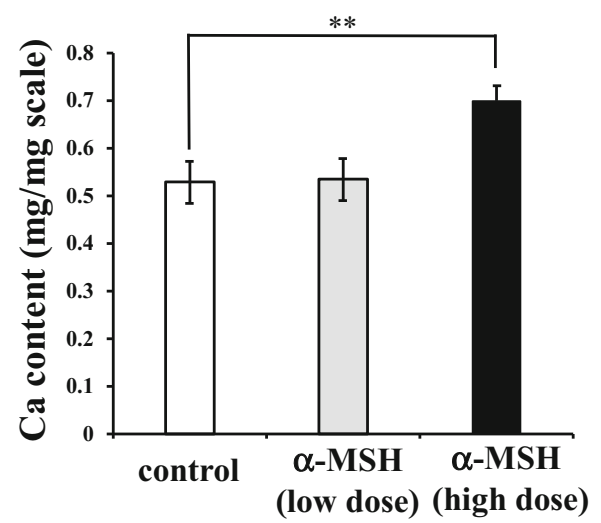

(b) Ontogenic scale

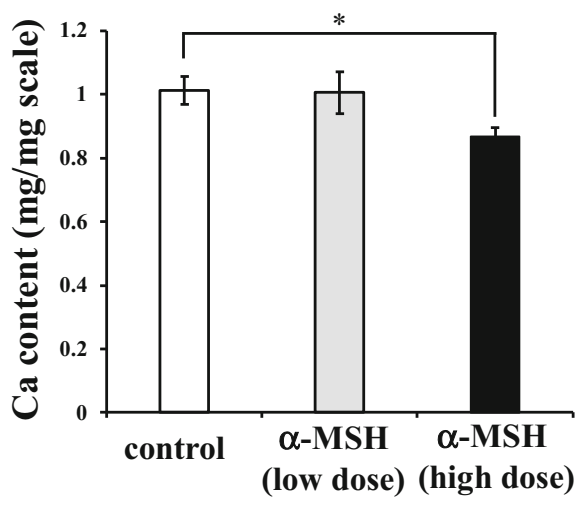

Fig. 3 Effects of $\alpha$-MSH on calcium content in regenerating and ontogenic goldfish scales. $\alpha$-MSH was injected at a low dose $(0.1 \mu \mathrm{g} / \mathrm{g}$ body weight $)$ or a high dose $(1 \mu \mathrm{g} / \mathrm{g}$ body weight $)$ into goldfish every other day. Ten days later, we analyzed the scalecalcium content in goldfish. * and **indicate statistically significant differences at $p<0.05$ and $p<0.01$, respectively, from the values in the control scales. $n=8$ samples; one sample from one fish 


\section{(a) Regenerating scales}

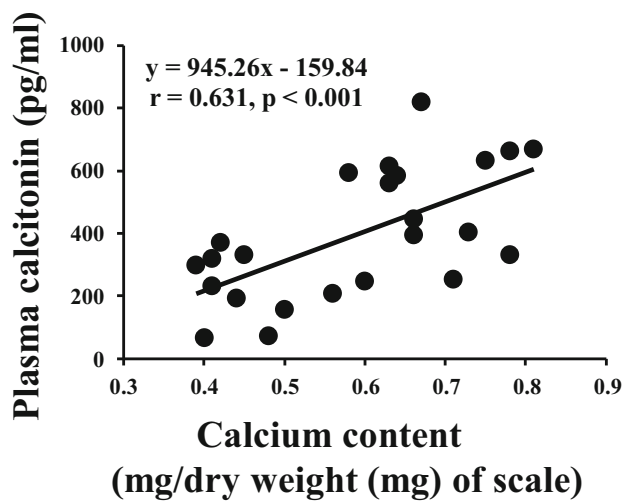

\section{(b) Ontogenic scales}

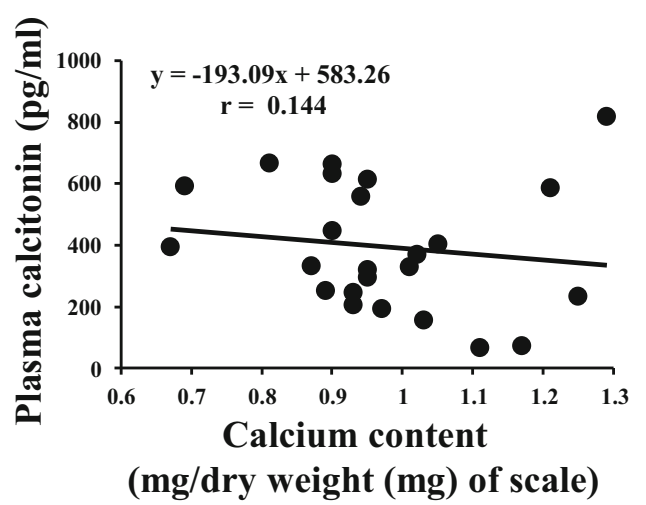

Fig. 4 Relationship between plasma calcitonin levels and scale-calcium content (a regenerating scales; b ontogenic scales). On the basis of data from Figs. 1 and 3, the relationship between plasma calcitonin level and scale-calcium content was examined. The data of control, low-dose-treated, and high-dose-treated goldfish were combined. There was a significant co-relationship $(r=0.631, p<0.001)$ between the plasma calcitonin and calcium content of regenerating scales

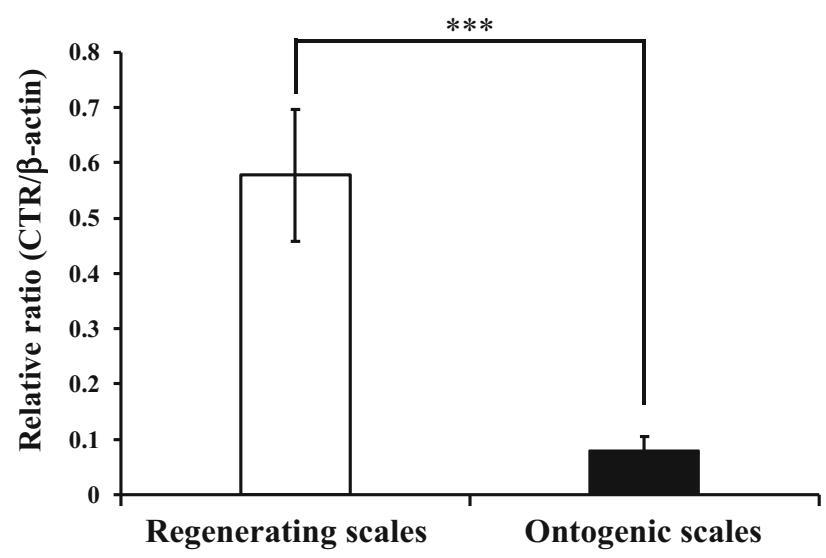

Fig. 5 Expression analysis of calcitonin receptor mRNA in regenerating and ontogenic scales. Ten days after removal of the scales, mRNA was prepared from regenerating and ontogenic scales. The mRNA expressions of calcitonin receptors were analyzed in scales. $* * *$ indicates a statistically significant difference at $p<0.001$ from the values in the control scales. $n=10$ samples; one sample from one fish. $\beta$-actin was used for normalization to each mRNA expression level

This implies that $\alpha$-MSH directly acts on ultimobranchial glands and promotes the secretion of calcitonin. We believe that the secreted calcitonin functions in regenerating scales and facilitates scale bone formation (Fig. 3a) because the plasma calcitonin level has a co-relationship with the calcium content of the regenerating scales (Fig. 4a) but not with the content of ontogenic scales (Fig. 4b). In addition, the calcitonin receptor mRNA expression in regenerating scales was significantly higher than that in ontogenic scales (Fig. 5), supporting the conclusion that calcitonin functions in regenerating scales.

In the brain of goldfish (Mizusawa et al. 2018) and the barfin flounder Verasper moseri (Takahashi et al. 2014), MCR1, 2, 3, 4, and 5 were expressed. In the case of goldfish ultimobranchial glands, MCR1, 2, 3, 4, and 5 were detected, although variation in the expression level of each individual was observed (Fig. 2). MCR mRNA expression in the ultimobranchial glands was different among individuals (Fig. 2). In male No. 2 and female Nos. 1 and 3, all MCRs were expressed in the ultimobranchial glands of goldfish. In other males (Nos. 1 and 3) and a female (No. 2), however, only two or three types of MCRs were detected in their ultimobranchial glands, at least in the present conditions. This MCR expression in ultimobranchial glands may be related to physiological conditions within individuals. In feeding, calcitonin has some functions in teleosts, as described in the "Introduction". In eels, Anguilla japonica (freshwater teleosts), and stonefish, Inimicus 
japonicus (marine teleosts), plasma calcitonin levels increased with the rise of plasma calcium caused by the dietary uptake of calcium (Suzuki et al. 1999; Kaida and Sasayama 2003). It is known that $\alpha$-MSH functions in feeding behavior (for a review, see Metz et al. 2006) and induces anorexigenic actions in goldfish (Kojima et al. 2010). During the feeding period, therefore, $\alpha$-MSH may have some relationship with calcitonin. In our next study, we would like to investigate the interaction between $\alpha$-MSH and calcitonin during feeding time.

We previously indicated that $\alpha$-MSH functions in scales and promotes bone resorption in goldfish (Ishizu et al. 2018). In ontogenic scales, the calcium content decreased (Fig. 3b), and might accelerate scale-bone resorption by $\alpha$-MSH. In regenerating scales, however, the calcium content increased (Fig. 3a), suggesting that calcitonin has some role in this phenomenon. Calcitonin is a hypocalcemic hormone resulting from the inhibition of osteoclastic activities in mammals (Azria 1989). Furthermore, in teleosts as well as mammals, it has been demonstrated that calcitonin suppresses osteoclastic activity (Suzuki et al. 2000; Sekiguchi et al. 2009, 2017). As goldfish-calcitonin suppressed osteoclastic activity in the scales of goldfish (Suzuki et al. 2000), calcitonin induced by $\alpha$-MSH-injection seems to function in regenerating scales and promoting scale regeneration.

On the other hand, we recently discovered a new function of calcitonin (Kase et al. 2017). We found that sardine procalcitonin was composed of procalcitonin amino-terminal cleavage peptide (N-proCT), calcitonin, and procalcitonin carboxyl terminal cleavage peptide (C-proCT). As compared with C-proCT, N-proCT has been highly conserved among teleosts, reptiles, and birds, which suggests that N-proCT has some bioactivities. To compare the bioactivities of calcitonin and N-proCT, we examined their bioactivities for osteoblasts and osteoclasts using our assay system with goldfish scales that consisted of osteoblasts and osteoclasts. As a result, sardine N-proCT $\left(10^{-7} \mathrm{M}\right)$ activated osteoblastic marker enzyme activity, while sardine calcitonin did not change. On the other hand, sardine calcitonin $\left(10^{-9}\right.$ to $\left.10^{-7} \mathrm{M}\right)$ suppressed osteoclastic marker enzyme activity, although sardine $\mathrm{N}$-proCT did not influence enzyme activity. In $\alpha$-MSH-injected goldfish, N-proCT might function in osteoblasts to regenerate scales and promote bone formation because osteoblastic activity and hormonal responses in regenerating scales were considerably higher than those in ontogenic scales (Yoshikubo et al. 2005). Rat-thyroid levels of calcitonin and N-proCT increase in parallel in vivo (Burns et al. 1989), suggesting that both calcitonin and N-proCT function in osteoclasts and osteoblasts, respectively, to regenerate scales.

Teleost scales are functional internal calcium reservoirs during periods of increased calcium demand (Mugiya and Watabe 1977; Bereiter-Hahn and Zylberberg 1993) and are a good model for analyzing bone metabolism (Vieira et al. 2011; de Vrieze et al. 2014a, b; Suzuki et al. 2016; Carnovali et al. 2016; Witten et al. 2017; Pinto et al. 2017). The osteogenesis in regenerating scales was very similar to that in calvarial bone (Yoshikubo et al. 2005; Thamamongood et al. 2012). In the present study, we can easily analyze $\alpha$-MSH function regarding bone metabolism. Thus, we conclude that regenerating scales can be utilized as a model for in vivo osteogenesis.

Acknowledgements This study was supported in part by grants to N.S. (Grant-in-Aid for Scientific Research [C] No. 16K07871 by JSPS, to T.S. (Grant-in-Aid for Scientific Research [C] No. 18K06312 by JSPS), and to A.H. (Grant-in-Aid for Scientific Research [C] No. 18K11016 by JSPS). This work was partly supported by the cooperative research program of the Institute of Nature and Environmental Technology, Kanazawa University, Accept Number 18014.

\section{Compliance with ethical standards}

Conflict of interest The authors have no competing interest to declare.

Open Access This article is distributed under the terms of the Creative Commons Attribution 4.0 International License (http:// creativecommons.org/licenses/by/4.0/), which permits unrestricted use, distribution, and reproduction in any medium, provided you give appropriate credit to the original author(s) and the source, provide a link to the Creative Commons license, and indicate if changes were made.

\section{References}

Azria M (1989) The calcitonins: physiology and pharmacology. Karger, Basel

Azuma K, Kobayashi M, Nakamura M, Suzuki N, Yashima S, Iwamuro S, Ikegame M, Yamamoto T, Hattori A (2007) Two osteoclastic markers expressed in multinucleate osteoclasts of goldfish scales. Biochem Biophys Res Commun 362:594-600 
Bereiter-Hahn J, Zylberberg L (1993) Regeneration of teleost fish scale. Comp Biochem Physiol A 105:625-641

Brzoska T, Luger TA, Maaser C, Abels C, Böhm M (2008) $\alpha$-melanocyte-stimulating hormone and related tripeptides: biochemistry, antiinflammatory and protective effects in vitro and in vivo, and future perspectives for the treatment of immune-mediated inflammatory diseases. Endocr Rev 29:581-602

Burns DM, Birnbaum RS, Roos BA (1989) A neuroendocrine peptide derived from the amino-terminal half of rat procalcitonin. Mol Endocrinol 3:140-147

Carnovali M, Luzi L, Banfi G, Mariotti M (2016) Chronic hyperglycemia affects bone metabolism in adult zebrafish scale model. Endocrine 54:808-817

Cornish J, Callon KE, Mountjoy KG, Bava U, Lin JM, Myers DE, Naot D, Reid IR (2003) $\alpha$-melanocyte-stimulating hormone is a novel regulator of bone. Am J Physiol Endocrinol Metab 284:E1181-E1190

de Vrieze E, Moren M, Metz JR, Flik G, Lie KK (2014a) Arachidonic acid enhances turnover of the dermal skeleton: studies on zebrafish scales. PLoS One 9:e89347

de Vrieze E, van Kessel MAHJ, Peters HM, Spanings FAT, Flik G, Metz JR (2014b) Prednisolone induces osteoporosis-like phenotype in regenerating zebrafish scales. Osteoporos Int 25:567-578

Dores RM, Liang L, Davis P, Thomas AL, Petko B (2016) 60 years of POMC: melanocortin receptors: evolution of ligand selectivity for melanocortin peptides. J Mol Endocrinol 56:T119-T133

Farooqi IS, Yeo GSH, Keogh JM, Aminian S, Jebb SA, Butler G, Cheetham T, O'Rahilly S (2000) Dominant and recessive inheritance of morbid obesity associated with melanocortin 4 receptor deficiency. J Clin Invest 106:271-279

Ikari T, Sekiguchi T, Urata M, Furusawa Y, Ikegame M, Kinoshita Y, Kitamura K, Nakabayashi I, Horita M, Tabuchi Y, Hattori A, Srivastav AK, Suzuki N (2018) Sequencing and expression analysis of calcitonin receptor in the scales of goldfish, Carassius auratus. Int J Zool Inv 4:1-10

Ishizu H, Sekiguchi T, Ikari T, Kitamura K, Kitani Y, Endo M, Urata M, Kinoshita Y, Hattori A, Srivastav AK, Mishima H, Mizusawa K, Takahashi A, Suzuki N (2018) $\alpha$-melanocyte-stimulating hormone promotes the bone resorption resulting from increased osteoblastic and osteoclastic activities in goldfish. Gen Comp Endocrinol 262:99-105

Kaida N, Sasayama Y (2003) Dynamics of plasma Ca and calcitonin levels in stonefish (Inimicus japonicus) administered a highCa solution into the stomach. Zool Sci 20:353-356

Kase Y, Ikari T, Sekiguchi T, Sato M, Ogiso S, Kawada T, Matsubara S, Satake H, Sasayama Y, Endo M, Kitamura K, Hattori A, Watanabe TX, Maruyama Y, Watanabe Y, Funahashi H, Kambegawa A, Suzuki N (2017) Sardine procalcitonin aminoterminal cleavage peptide has a different action from calcitonin and promotes osteoblastic activity in the scales of goldfish. Comp Biochem Physiol A 211:77-83

Kobayashi Y, Chiba H, Mizusawa K, Suzuki N, Cerdá-Reverter JM, Takahashi A (2011) Pigment-dispersing activities and cortisol-releasing activities of melanocortins and their receptors in xanthophores and head kidneys of the goldfish Carassius auratus. Gen Comp Endocrinol 173:438-446

Kojima K, Amiya N, Kamijo M, Kageyama H, Uchiyama M, Shioda S, Matsuda K (2010) Relationship between $\alpha$-melanocytestimulating hormone- and neuropeptide Y-containing neurons in the goldfish hypothalamus. Gen Comp Endocrinol 167:366-372

Metz JR, Peters JJM, Flik G (2006) Molecular biology and physiology of the melanocortin system in fish: a review. Gen Comp Endocrinol 148:150-162

Mizusawa K, Yamamura Y, Kasagi S, Cerdá-Reverter JM, Takahashi A (2018) Expression of genes for melanotropic peptides and their receptors for morphological color change in goldfish Carassius auratus. Gen Comp Endocrinol 264:138-150

Mugiya Y, Watabe N (1977) Studies on fish scale formation and resorption II: effect of estradiol on calcium homeostasis and skeletal tissue resorption in the goldfish, Carassius auratus, and the killifish, Fundulus heteroclitus. Comp Biochem Physiol A 57:197-202

Pinto PIS, Estêvão MD, Santos S, Andrade A, Power DM (2017) In vitro screening for estrogenic endocrine disrupting compounds using Mozambique tilapia and sea bass scales. Comp Biochem Physiol C 199:106-113

Sato M, Yachiguchi K, Motohashi K, Yaguchi Y, Tabuchi Y, Kitani Y, Ikaria T, Ogiso S, Sekiguchi T, Hai TN, Huong DTT, Hoang NV, Urata M, Mishima H, Hattori A, Suzuki N (2017) Sodium fluoride influences calcium metabolism resulting from the suppression of osteoclasts in the scales of nibbler fish Girella punctate. Fish Sci 83:543-550

Sekiguchi T, Suzuki N, Fujiwara N, Aoyama M, Kawada T, Sugase K, Murata Y, Sasayama Y, Ogasawara M, Satake H (2009) Calcitonin in a protochordate, Ciona intestinalis: the prototype of the vertebrate calcitonin/calcitonin gene related peptide superfamily. FEBS J 276:4437-4447

Sekiguchi T, Shiraishi A, Satake H, Kuwasako K, Takahashi H, Sato M, Urata M, Wada S, Endo M, Ikari T, Hattori A, Srivastav AK, Suzuki N (2017) Calcitonin-typical suppression of osteoclastic activity by amphioxus calcitonin superfamily peptides and insights into the evolutionary conservation and diversity of their structures. Gen Comp Endocrinol 246:294-300

Suzuki N (2001) Calcitonin-like substance in the plasma of Cyclostomata and its putative role. Comp Biochem Physiol B 129:319-326

Suzuki N, Suzuki D, Sasayama Y, Srivastav AK, Kambegawa A, Asahina K (1999) Plasma calcium and calcitonin levels in eels fed a high calcium solution or transferred to seawater. Gen Comp Endocrinol 114:324-329

Suzuki N, Suzuki T, Kurokawa T (2000) Suppression of osteoclastic activities by calcitonin in the scales of goldfish (freshwater teleost) and nibbler fish (seawater teleost). Peptides 21:115-124

Suzuki N, Yamamoto K, Sasayama Y, Suzuki T, Kurokawa T, Kambegawa A, Srivastav AK, Hayashi S, Kikuyama S (2004) Possible direct induction by estrogen of calcitonin secretion from ultimobranchial cells in the goldfish. Gen Comp Endocrinol 138:121-127

Suzuki N, Somei M, Seki A, Reiter RJ, Hattori A (2008) Novel bromomelatonin derivatives as potentially effective drugs to treat bone diseases. J Pineal Res 45:229-234 
Suzuki N, Kitamura K, Omori K, Nemoto T, Satoh Y, Tabata MJ, Ikegame M, Yamamoto T, Ijiri K, Furusawa Y, Kondo T, Takasaki I, Tabuchi Y, Wada S, Shimizu N, Sasayama Y, Endo M, Takeuchi T, Nara M, Somei M, Maruyama Y, Hayakawa K, Shimazu T, Shigeto Y, Yano S, Hattori A (2009) Response of osteoblasts and osteoclasts in regenerating scales to gravity loading. Biol Sci Space 23:211-217

Suzuki N, Danks JA, Maruyama Y, Ikegame M, Sasayama Y, Hattori A, Nakamura M, Tabata MJ, Yamamoto T, Furuya R, Saijoh K, Mishima H, Srivastav AK, Furusawa Y, Kondo T, Tabuchi Y, Takasaki I, Chowdhury VS, Hayakawa K, Martin TJ (2011) Parathyroid hormone 1 (1-34) acts on the scales and involves calcium metabolism in goldfish. Bone 48:1186-1193

Suzuki N, Kitamura K, Hattori A (2016) Fish scale is a suitable model for analyzing determinants of skeletal fragility in type 2 diabetes. Endocrine 54:575-577

Takahashi A, Kawauchi H (2006) Evolution of melanocortin systems in fish. Gen Comp Endocrinol 148:85-94

Takahashi A, Mizusawa K (2013) Posttranslational modifications of proopiomelanocortin in vertebrates and their biological significance. Front Endocrinol 4:143

Takahashi A, Mizusawa K, Amano M (2014) Multifunctional roles of melanocyte-stimulating hormone and melaninconcentrating hormone in fish: evolution from classical body color change. Aqua BioSci Monogr 7:1-46

Thamamongood TA, Furuya R, Fukuba S, Nakamura M, Suzuki N, Hattori A (2012) Expression of osteoblastic and osteoclastic genes during spontaneous regeneration and autotransplantation of goldfish scale: a new tool to study intramembranous bone regeneration. Bone 50:1240-1249

Vieira FA, Gregório SF, Ferraresso S, Thorne MA, Costa R, Milan M, Bargelloni L, Clark MS, Canario AVM, Power DM (2011) Skin healing and scale regeneration in fed and unfed sea bream, Sparus auratus. BMC Genom 12:490

Witten PE, Harris MP, Huysseune A, Winkler C (2017) Small teleost fish provide new insights into human skeletal diseases. Methods Cell Biol 138:321-346

Yoshikubo H, Suzuki N, Takemura K, Hoso M, Yashima S, Iwamuro S, Takagi Y, Tabata MJ, Hattori A (2005) Osteoblastic activity and estrogenic response in the regenerating scale of goldfish, a good model of osteogenesis. Life Sci 76:2699-2709

\section{Publisher's Note}

Springer Nature remains neutral with regard to jurisdictional claims in published maps and institutional affiliations. 